\title{
Defining, Rationalising and Measuring Digital Towns
}

\subsection{INTRODUCTION}

The European Union's (EU) 'Digital Society' is the latest in a long line of 'revolutions', 'ages' and societal forms proposed by policymakers, academics and industry for over fifty years (Martin, 2008; Lynn et al., 2018). Critics note that it is at best inaccurate and at worst incorrect to describe society as digital or of technological origin, and is not by and large subject to sudden unexpected phase transitions inherent in revolutions (Martin, 2008). Nonetheless, digital technologies are influencing, and in many cases transforming, how society operates and how social actors interact with each other (Martin, 2008; Reis et al., 2018). Furthermore, there is a well-established literature base regarding the potential benefits of digital technologies for society (Mossberger et al., 2007). The EU's vision of a European digital society is an inclusive one based on "building smarter cities, improving access to eGovernment, eHealth services and digital skills" (European Commission, 2021), and yet for many such a digital society can seem ambiguous, distant, and beyond their technical abilities and imagination.

Over the same time that our conceptualisation of a society permeated and transformed by technologies evolved, there was and continues to be a parallel shift in where and how we live. Since 1975, there has been a rise in the proportion of the global population that live in cities from $37 \%$ in 1975 to $48 \%$ today (OECD and European Union, 2020). Attracted by the perceived economic opportunities and quality of life in cities, rural

(C) The Author(s) 2022

T. Lynn et al., Digital Towns, https://doi.org/10.1007/978-3-030-91247-5_1 
populations have migrated to cities contributing to their expansion and densification (OECD and European Union, 2020; Lerch, 2017). The socio-cultural, political, and economic benefits of urban agglomeration bring significant challenges in sustainable development, not least pollution, crime, and health issues (OECD and European Union, 2020). So-called 'smart city' technologies are touted as solutions to modern urban problems but what about the rest, the other $52 \%$ who don't live in cities?

For those who live in and depend on rural towns to participate fully in a digital society requires an understanding of what digitalisation means in its widest sense, and to imagine alternatives to the current city-centric narrative (Dufva \& Dufva, 2019). The remainder of this chapter begins with a brief overview of key terms and concepts followed by a discussion of the urban-rural digital divide. This is followed by a review and discussion of the rationales for increased adoption and use of digital technologies in rural areas and specifically towns. Based on this review, we propose a working definition of a Digital Town. We conclude with a discussion on the need for a discrete measurement framework to measure the digital readiness of a digital society.

\subsection{Digital Society-Key Concepts and Terms}

Understanding and conceptualising what constitutes a digital society is made more complex by its situation at the intersection of the virtual, physical, and social. To make sense, exist fully, and imagine a future society permeated by digital technologies requires understanding not only the digital and physical world in themselves, but the relationships between the various entities in each of these worlds and between them, a space which is a form of mixed reality. Furthermore, the perspectives taken by different actors can vary substantially, from macro to micro levels.

\subsubsection{What Do We Mean by Digital?}

When we refer to the digital society or even a digital town, we do not mean that, as Martin (2008) states, it is "[...]made by the digital, and that its essential characteristics have been created because of the development of digital technology." But what do we mean? The answer to this question is not simple. 
A significant challenge noted in recent reviews is that terms like Industry 4.0 and Digital Transformation, while widely cited, lack agreement on meaning (Reis et al., 2018; Vial, 2019; Nosalska et al., 2019; Culot et al., 2020 ). Indeed, whether one is referring to the information society or digital society etc., there would appear to be two major categories. To paraphrase Webster (2006), there are those who endorse or promote the idea of a digital society or information society, and those who see digitalisation or informatisation as the continuation of pre-established relations, a subordinate feature of established social systems. As Webster (2006) puts it, the former emphasise change while the latter emphasise persistence. These need not be binary. Table 1.1 below briefly summarises highly cited and prominent definitions of common terms and concepts with respect to digital society.

Table 1.1 Key terms and concepts in the digital society literature

\begin{tabular}{|c|c|}
\hline Term & Definition \\
\hline Digital Citizen & $\begin{array}{l}\text { The citizen subject acting through the internet (Isin \& Ruppert, 2020). } \\
\text { Isin and Ruppert (2020) suggest that the digital citizens only come into } \\
\text { being through digital acts and making rights claims. }\end{array}$ \\
\hline Digital City & $\begin{array}{l}\text { (1) A city that is being transformed or re-oriented through digital } \\
\text { technology, or (2) a digital representation or reflection of some aspects } \\
\text { of an actual or imagined city (Schuler, 2001). }\end{array}$ \\
\hline Digital & All economic activity reliant on, or significantly enhanced by the use of \\
\hline Economy & $\begin{array}{l}\text { digital inputs, including digital technologies, digital infrastructure, } \\
\text { digital services and data. It refers to all producers and consumers, } \\
\text { including government, that are utilising these digital inputs in their } \\
\text { economic activities (G20 Digital Economy Task Force, 2020). }\end{array}$ \\
\hline Digital Society & $\begin{array}{l}\text { A society whose social structures and activities, to a greater or lesser } \\
\text { extent, are organised around digital information networks that connect } \\
\text { people, processes, things, data and networks (Lynn et al., 2018). Also, } \\
\text { sometimes referred to as the Internet of Everything. }\end{array}$ \\
\hline Digitisation & $\begin{array}{l}\text { The process of changing from analogue to digital form, also known as } \\
\text { digital enablement (Gartner, 2021). }\end{array}$ \\
\hline Digitalisation & $\begin{array}{l}\text { The act(s) of transforming various previously physical or analogue } \\
\text { actions into digital data systems (Dufva \& Dufva, 2019). This includes } \\
\text { processes, interactions, and business models. }\end{array}$ \\
\hline Digitality & Living in a digital and digitised culture (Negroponte, 2015). \\
\hline Digital & A process where digital technologies create disruptions triggering \\
\hline Transformation & $\begin{array}{l}\text { strategic responses from organisations that seek to alter their value } \\
\text { creation paths while managing the structural changes and organisational } \\
\text { barriers that affect the positive and negative outcomes of this process } \\
\text { (Vial, 2019). }\end{array}$ \\
\hline
\end{tabular}


Table 1.1 (continued)

\begin{tabular}{|c|c|}
\hline Term & Definition \\
\hline Industry 4.0 & $\begin{array}{l}\text { A concept of organisational and technological changes along with value } \\
\text { chains integration and new business models development that are } \\
\text { driven by customer needs and mass customisation requirements and } \\
\text { enabled by innovative technologies, connectivity and IT integration } \\
\text { (Nosalska et al., 2019). Also referred to as the Fourth Industrial } \\
\text { Revolution (4IR). }\end{array}$ \\
\hline Information & A society in which information is the defining feature. Webster (2006) \\
\hline Society & $\begin{array}{l}\text { notes that there are two categories of definitions, those organised } \\
\text { around the quantitative measures of information expansion, and those } \\
\text { that suggests an information society is one in which a decisive } \\
\text { qualitative change has taken place with regard to the ways in which } \\
\text { information is used. In the latter, Webster }(2006) \text { defines an } \\
\text { information society is defined as one in which theoretical knowledge } \\
\text { occupies a pre-eminence which it hitherto lacked, but suggests this may } \\
\text { be more correctly referred to as a "Knowledge Society." }\end{array}$ \\
\hline Networked City & $\begin{array}{l}\text { A multitude of social networks comprising systems of interaction, } \\
\text { systems of resource allocation, and systems of integration and } \\
\text { coordination (Craven \& Wellman, 1973). }\end{array}$ \\
\hline Smart City & $\begin{array}{l}\text { A smart city is a well-defined geographical area, in which high } \\
\text { technologies such as ICT, logistic, energy production, and so on, } \\
\text { cooperate to create benefits for citizens in terms of well-being, inclusion } \\
\text { and participation, environmental quality, intelligent development; it is } \\
\text { governed by a well-defined pool of subjects, able to state the rules and } \\
\text { policy for the city government and development (Dameri, 2013). }\end{array}$ \\
\hline
\end{tabular}

\subsubsection{Mainstream vs Frontier Technologies}

When one considers digital technologies, we are faced with what Chambers (2010) calls a 'cornucopia of potentials' much more than can be covered within the confines of this chapter. As such, it is important to differentiate between mainstream technologies and frontier or emerging technologies. While the former are widely used in society and are considered relatively normal and conventional, frontier technologies represent technological advancements on previous generations of technologies and offer potential disruption. They are defined by their emergent use, their potential. Mainstream technologies include office productivity software, mobile technologies (incl. smartphones), websites, social media, and basic forms of cloud computing. Frontier technologies are often referred to as emerging technologies as they lack widespread adoption in society. In their most 
recent report, UNCTAD references eleven such technologies summarised in Table 1.2 below. The use of these technologies by society as a whole, by definition, is at a nascent stage although they represent significant markets already (UNCTAD, 2021). Similarly, some technologies are further along the adoption cycle than others. In addition to native digital technologies, frontier technologies are often enabled by digital technologies (e.g., gene editing), enter mainstream use through incorporation into general purpose technologies (e.g., artificial intelligence and nanotechnology), or enable (more efficient) access and use to digital technologies (e.g., solar photovoltaic power).

Table 1.2 Selected frontier technologies and definitions (adapted from UNCTAD, 2021)

\begin{tabular}{l} 
Technology \\
\hline Artificial Intelligence (AI) \\
Internet of Things (IoT) \\
Big Data \\
Blockchain \\
Next Generation Networks \\
(NGN)/Next Generation \\
Access \\
3D Printing / Additive \\
Manufacturing \\
Robotics
\end{tabular}

Drones / Unmanned Aerial Vehicle (UAV)

Gene Editing

Nanotechnology

Solar Photovoltaic (Solar PV)
Description

The capability of a machine to engage in cognitive activities typically performed by the human brain. Internet-enabled physical devices that can collect and share data.

Datasets whose size or type is beyond the ability of traditional database structures to capture, manage and process.

An immutable time-stamped series of data records supervised by a cluster of computers not owned by any single entity.

While UNCTAD (2021) refers to 5G, NGN/NGA is widely used and refers to the next generation of mobile internet access and connectivity.

The production of three-dimensional objects based on a digital file.

Programmable machines that can carry out actions and interact with the environment via sensors and actuators either autonomously or semi-autonomously.

A flying robot that can be remotely controlled or fly autonomously using software with sensors and GPS. A genetic engineering tool to insert, delete or modify the genome in organisms.

A field of applied science and technology dealing with the manufacturing of objects in scales smaller than 1 micrometre.

Technology that transforms sunlight into direct current electricity using semiconductors within PV cells. 


\subsection{What Is a Town?}

While national and global definitions tend to agree on what cities are, national definitions tend to disagree on the classification of towns, semidense areas and rural areas (OECD and European Union, 2020). These definitional challenges reduce comparability and do not recognise governance differences (Lynn et al., 2020). Recently, a consortium of international organisations addressed this issue through the introduction of two new definitions, the degree of urbanisation and the functional urban area (FUA) (OECD and European Union, 2020). The FUA recognises that cities are metropolitan areas comprising the city itself and surrounding areas that are connected to the city in terms of labour market interactions (commuting zones) (Dijkstra et al., 2019). The degree of urbanisation reflects an urban-rural continuum and proposes three classes:

- Cities consist of contiguous grid cells that have a density of at least 1 500 inhabitants per $\mathrm{km}^{2}$ are at least $50 \%$ built up with a population of at least 50,000 .

- Towns and semi-dense areas (TSA) consist of contiguous grid cells with a density of at least 300 inhabitants per $\mathrm{km}^{2}$, are at least $3 \%$ built up, and have a total population of at least 5000 .

- Rural areas are cells that do not belong to a city or a town and semidense area, and for the most part have a density below 300 inhabitants per $\mathrm{km}^{2}$ (OECD and European Union, 2020).

\subsection{The Urban-Rural Digital Divide}

While commonly used, the term digital divide, in reality, refers to a variety of interrelated digital divides. Philip et al. (2017) highlights two such divides-(i) divides resulting from inequalities in the technological infrastructure required to support digital connectivity, and (ii) socio-economic digital divides. These aspects have been explored in the urban-rural context for over two decades (Philip et al., 2017; Hindman, 2000; Townsend et al., 2013). Others view the digital divide across three levels-Internet access (first-level digital divide), Internet skills and use (second-level digital divide), and tangible outcomes of Internet use (third-level divide) 
(Scheerder et al., 2017; Wei \& Hindman, 2011). These two perspectives are clearly not mutually exclusive.

We define the urban-rural divide as an inequality between urban and rural areas with respect to the adoption and use of digital technologies, and the beneficial outcomes resulting from such adoption and use. The hypothesis underpinning this divide is that rural areas present lesser access and use of technologies, and consequently experience less beneficial outcomes, than urban areas. Firstly, inequalities in access and use are not disputed. There is substantial evidence that rural areas experience less availability and less access to infrastructure (Philip et al., 2017; Ashmore et al., 2015; Ali et al., 2020). Furthermore, studies in highly digitised countries such as South Korea and Australia suggest that the digital divide extends to a difference in use by and perceived benefits for rural users (Park \& Kim, 2015; Park, 2017). In addition to broadband availability, geographic remoteness and suitability, and social exclusion are some of the factors that have been cited as barriers to digital adoption and use in rural areas (Park \& Kim, 2015; Park, 2017; Ali et al., 2019). This is consistent with Philip et al. (2017). Unfortunately, as Scheerder et al. (2017) point out there is a general lack of research on the third-level digital divide i.e., relating to the beneficial outcomes of digital adoption and use. What research exists is fragmented. The limited literature on the urban-rural digital divide does present regional differences but is not comprehensive in scope or particularly current. Regional differences, supporting the urban-rural digital divide hypothesis, are reported for economics and other daily activities (Stern et al., 2009), e-payment and online shopping (Hsieh et al., 2013), parental mediation of adolescent internet use and adolescent exposure to internet risk and harm (Chang et al., 2016), institutional outcomes (Van Deursen \& Helsper, 2015), and educational outcomes ( $\mathrm{Li} \&$ Ranieri, 2013). In many cases, these are related to socio-economic factors including age, income, gender, and education.

These interrelated factors may not be capable of being addressed by the market or government intervention alone, particularly where structural and geographic conditions make broadband deployment commercially infeasible or unattractive. Community-led multi-stakeholder initiatives have been suggested as a solution to the urban-rural digital divide however such initiatives need to overcome access to technical expertise, volunteerism, and funding arrangements, as well as geographical conditions to ensure success (Ashmore et al., 2015). 


\subsection{Rationalising and Defining Digital Towns}

Borrowing from Hawkridge (1990) and based on analysis of existing community network and digital town projects, we identify at least ten rationales for digital town initiatives (Table 1.3). Eight of these can be organised along a socio-economic spectrum-Social, Accessibility, Pedagogical, Vocational, Sustainability, Quality of Service, Catalytic, Economic. The proposed Reactive rationale differs in that it represents a short term response to a crisis such as COVID-19; if continued it would likely be rationalised using one of the other rationales. The Opportunistic rationale differs in that it is over-riding.

Table 1.3 Rationales for digital towns

\begin{tabular}{ll}
\hline Rationale & Description \\
\hline Social & The Social Rationale recognises that towns are part of a wider digital \\
society and digital technologies help towns and their residents participate \\
and function more fully in such a digital society (da Rocha, 2002; \\
McQuillan, 2001; Hervé-Van Driessche, 2001). In many instances, this \\
revolves around the provision of online platforms where stakeholders can \\
share and consume information, services, and transact through \\
marketplaces (Digitale Doerfer, 2020; Zavratnik et al., 2018). \\
The Accessibility Rationale posits that the adoption and use of digital \\
technologies can increase accessibility to services and opportunities to \\
those who may be disadvantaged or vulnerable in society (da Rocha, \\
2002). \\
The Pedagogical Rationale posits that digital technologies will enhance \\
teaching and learning (Hawkridge, 1990; Nusche \& Minea-Pic, 2020). \\
Distinct from the vocational rationale, here the focus is on the use of \\
digital technologies to support the process of learning and teaching, and \\
the achievement of educational outcomes, inside the classroom, at the \\
educational institution, at home, or elsewhere (Nusche \& Minea-Pic, \\
2020). \\
The Vocational Rationale argues that citizens should be prepared to work \\
in a digital society (European Network for Rural Development, 2018; \\
McQuillan, 2001). This includes embedding digital technologies in \\
educational institutions, the provision of education and training on digital \\
technologies and related topics, and the overall digital competencies for \\
the entire community (McQuillan, 2001; Hervé-Van Driessche, 2001). \\
For example, Aveiro had a specific focus on training and providing \\
employment opportunities for citizens with special needs in their digital \\
town programme (da Rocha, 2002). \\
Vocational
\end{tabular}

(continued) 
Table 1.3 (continued)

\begin{tabular}{|c|c|}
\hline Rationale & Description \\
\hline Sustainability & $\begin{array}{l}\text { Unsurprisingly, environmental sustainability is a common rationale for } \\
\text { digital town projects. Here, the adoption and use of digital technologies } \\
\text { is seen as a means for towns to reduce adverse environmental impacts and } \\
\text { build a resilient habitat for existing and future residents (European } \\
\text { Network for Rural Development, 2018; Hsieh et al., 2011; Sakurai \& } \\
\text { Kokuryo, 2018). }\end{array}$ \\
\hline $\begin{array}{l}\text { Quality of } \\
\text { Service }\end{array}$ & $\begin{array}{l}\text { A number of digital town objectives can be categorised under a Quality } \\
\text { of Service Rationale. This rationale assumes that digital technologies may } \\
\text { increase the range, quality and efficiency of service delivery whether } \\
\text { public services (including health services), commercial services, or } \\
\text { community services (da Rocha, 2002; Hervé-Van Driessche, 2001; } \\
\text { Wichmann et al., 2021). }\end{array}$ \\
\hline Catalytic & $\begin{array}{l}\text { A common theme in digital town projects is the role of digital } \\
\text { technologies as a catalyst of other innovations from all parts of the } \\
\text { community (Hosseini et al., 2018; da Rocha, 2002; Hervé-Van } \\
\text { Driessche, 2001). Indeed, in the case of Parthenay, a specific objective of } \\
\text { the digital town programme was to explore whether citizens were capable } \\
\text { of co-inventing services with the public and commercial sponsors } \\
\text { (Hervé-Van Driessche, 2001). }\end{array}$ \\
\hline Economic & $\begin{array}{l}\text { Many digital agenda and digital town initiatives are driven, at some level, } \\
\text { by an Economic Rationale. This rationale posits that the availability, } \\
\text { quality (including broadband speed), adoption and use of digital } \\
\text { technologies may attract greater economic growth and employment to a } \\
\text { town (Hervé-Van Driessche, 2001). This includes increased tourism and } \\
\text { retail activity in addition to potentially attracting digital industry } \\
\text { investment and teleworkers (Wichmann et al., 2021). For example, in the } \\
\text { German Digital Doerfer project, the platform includes a service for } \\
\text { ordering and delivering local products and services (Digitale Doerfer, } \\
2020 \text { ). }\end{array}$ \\
\hline Reactive & $\begin{array}{l}\text { Against the backdrop of COVID-19, it is reasonable to posit that towns } \\
\text { and constituent stakeholders might adopt digital technologies in response } \\
\text { to a crisis, in this case a global pandemic. There is substantial evidence of } \\
\text { all aspects of society adopting digital technologies to deliver services and } \\
\text { maintain relationships with stakeholders during the COVID-19 pandemic } \\
\text { and lock-down (Lynn et al., 2022; Baig et al., 2020). }\end{array}$ \\
\hline Opportunistic & $\begin{array}{l}\text { Finally, although somewhat implicitly, digital towns appear to be } \\
\text { motivated by an Opportunistic Rationale in that the adoption and use of } \\
\text { digital technologies can differentiate a town from other towns and may } \\
\text { make it a more attractive place to live, work or visit, or competitive from } \\
\text { an economic and investment perspective, when compared to other towns. } \\
\text { This rationale has a dual purpose in that towns not only seek to attract } \\
\text { new residents, workers and visitors to the town but retain existing } \\
\text { residents and mitigate the risk of depopulation (European Network for } \\
\text { Rural Development, 2018). }\end{array}$ \\
\hline
\end{tabular}


These rationales are reflected in three prevailing perspectives on digital towns in the literature, which we label as infrastructure-centric, servicecentric, and community-centric. The Infrastructure perspective of a digital town emphasises the local availability and appropriation of ICT infrastructure as a prerequisite for the connection of a town as a node in a national/ global network. The Service perspective emphasises the provision of local information services for citizen's everyday lives and visitors. Finally, the Community perspective emphasises platforms for communities of interest to support work in a geographical and information space where users can interact, sharing knowledge, experience and mutual interests (Hervé-Van Driessche, 2001). In reality, a digital town is all of these things. ${ }^{1}$

Consequently, we define a digital town as:

A geographic and information space that adopts and integrates information and communication technologies in all aspects of town life where a town consists of contiguous grid cells with a density of at least 300 inhabitants per $\mathrm{km}^{2}$, are at least 3\% built up, and have a total population of at least 5,000.

\subsection{The Need for a Discrete Digital Town Measurement Framework}

Performance management and measurement literature suggests that making strategy more measurable enables decision makers to take corrective actions to keep the organisation on track (de Waal, 2007). Furthermore, by providing critical success factors and indicators necessary for success, organisations and individuals can set goals which, in themselves, may influence performance particularly when specific feedback is provided on progress towards achieving said goals (de Waal \& Kourtit, 2013).

Measurement frameworks and composite indices are used widely in policymaking and in particular to measure performance, relative progress or competitiveness through benchmarking, and identify areas of excellence or areas for improvement (Foley et al., 2018). As the G20 Digital Economy Task Force (DETF) $(2018$, p. 4) stated in the introduction to the G20 Toolkit for measuring the digital economy:

\footnotetext{
${ }^{1}$ Given the renewed interest in the metaverse, it is important that any definition of digital town is sufficiently broad to accommodate the physical world, virtual reality, and the comingling of both through augmented reality or other forms of hyper-reality.
} 
Sound measurement is crucial for informing and guiding policymaking, as it helps policymakers produce precise diagnostics, assess the potential of alternative policy options, monitor progress, and evaluate the efficiency and efficacy of implemented policy actions.

The measurement of digital progress is not a new idea. Since the turn of the century, a wide range of frameworks and composite indices have been proposed for assessing digital adoption and use by policymakers, scholars, and international organisations (G20 Digital Economy Task Force, 2018). ${ }^{2}$ Table 1.4 summarises commonly cited international frameworks and composite indices; links to each framework are provided in the Useful Links section at the end of the book. Initially, these measures were dominated by the desire to quantify the economic impact of digital technology adoption and use. While approaches and indicators to measure the progress towards a digital society as a whole have emerged, for example, the European Union (EU) Digital Economy and Society Index (DESI), the economic imperative has remained the dominant perspective as evidenced in the recent G20 DETF roadmap for measuring the digital economy (G20 Digital Economy Task Force, 2020). As such, existing approaches and indicators mostly focus on national economic indicators. Notwithstanding this, there have been recent efforts to assess the state and evolution of digital progress at more granular levels. For example, both the IMD-SUTD Smart City Index (Bris et al., 2019) and CityKeys framework present a set of city-level indicators (Bosch et al., 2017). These proposals are largely in the smart city domain and as such often conflate both digital and environmental sustainability themes.

In general terms, there are pros and cons to using rankings and composite indicators. As well as informing both policy making and administration, they can also seek to inform and guide the public on the relative success of policy and/or initiatives (Berger \& Bristow, 2009). Furthermore, rankings and composite indicators can help summarise complex issues and reduce complexity thereby improving interpretability (Berger \& Bristow, 2009). At the same time, such rankings and indicators have been criticised for being too simplistic and condensed and presenting an objective and

\footnotetext{
${ }^{2}$ Section 4 of the G20 Toolkit for Measuring the Digital Economy includes overviews of frameworks and indicators for measuring various aspects of the digital economy from Argentina, Australia, Brazil, Canada, China, France, Germany, Japan, Korea, Mexico, Russia, Saudi Arabia, Singapore, Turkey, the United Kingdom, and the United States of America.
} 
Table 1.4 Selected international digital society and digital economy measurement frameworks and composite indices

\begin{tabular}{|c|c|c|}
\hline Framework & Description & Source \\
\hline $\begin{array}{l}\text { Digital Economy \& } \\
\text { Society Index (DESI) }\end{array}$ & $\begin{array}{l}\text { Measures performance across five } \\
\text { dimensions: } \\
\text { 1. Connectivity } \\
\text { 2. Digital Skills } \\
\text { 3. Use of Internet } \\
\text { 4. Integration of Digital Technology } \\
\text { 5. Digital Public Services }\end{array}$ & $\begin{array}{l}\text { Digital Economy and } \\
\text { Skills Unit (2018, } \\
2020,2021)\end{array}$ \\
\hline Digital Capital Index & $\begin{array}{l}\text { Measures digital capital based on two } \\
\text { dimensions: } \\
\text { 1. Digital competencies } \\
\text { - information and data literacy } \\
\text { - communication and collaboration } \\
\text { - digital content creation, } \\
\text { - safety } \\
\text { - problem solving. } \\
\text { and } \\
\text { 2. Digital access } \\
\text { - access to digital equipment, } \\
\text { - connectivity (quality and place) } \\
\text { - historical time spent online } \\
\text { - support and training }\end{array}$ & $\begin{array}{l}\text { Ragnedda et al. } \\
(2020)\end{array}$ \\
\hline $\begin{array}{l}\text { Digital Planet- } \\
\text { Digital Evolution } \\
\text { Index }\end{array}$ & $\begin{array}{l}\text { The competitiveness of a country's digital } \\
\text { economy is a function of two factors: } \\
\text { 1. its current state of digitisation based on } \\
\text { four drivers( } 99-170 \text { indicators): } \\
\text { - supply conditions } \\
\text { - demand conditions } \\
\text { - institutional environment } \\
\text { - innovation and change } \\
\text { and } \\
2 \text {. its pace of digitisation (momentum) } \\
\text { over time measured by the growth rate of } \\
\text { a country's digitisation score over a } \\
\text { ten-year period }\end{array}$ & $\begin{array}{l}\text { Chakravorti et al. } \\
(2015)\end{array}$ \\
\hline
\end{tabular}


Table 1.4 (continued)

\begin{tabular}{|c|c|c|}
\hline Framework & Description & Source \\
\hline $\begin{array}{l}\text { Digital Ecosystem } \\
\text { Development Index }\end{array}$ & $\begin{array}{l}64 \text { indicators organised in to } 8 \text { pillars: } \\
\text { 1. Institutional and regulatory } \\
\text { 2. Connectivity } \\
\text { 3. Infrastructure } \\
\text { 4. Factors of production } \\
\text { 5. Household digitisation } \\
\text { 6. Competition } \\
\text { 7. Digitisation of production } \\
\text { 8. Digital industry }\end{array}$ & $\begin{array}{l}\text { Katz et al. (2014), } \\
\text { Katz and Callorda } \\
(2018)\end{array}$ \\
\hline $\begin{array}{l}\text { G20 Toolkit for } \\
\text { Measuring the Digital } \\
\text { Economy }\end{array}$ & $\begin{array}{l}\text { Over } 30 \text { key indicators organised in } 4 \\
\text { themes: } \\
\text { 1. Infrastructure } \\
\text { 2. Empowering society } \\
\text { 3. Innovation and technology adoption } \\
\text { 4. Jobs and growth }\end{array}$ & $\begin{array}{l}\text { G20 Digital } \\
\text { Economy Task Force } \\
(\text { DETF })(2018)\end{array}$ \\
\hline $\begin{array}{l}\text { ICT Development } \\
\text { Index }{ }^{\mathrm{a}}\end{array}$ & $\begin{array}{l}\text { Comprises three sub-indices and } 11 \\
\text { indicators: } \\
\text { 1. ICT Access } \\
\text { 2. ICT Use } \\
\text { 3. ICT Skills }\end{array}$ & ITU (2018) \\
\hline $\begin{array}{l}\text { I-DESI } \\
\text { Partnership on } \\
\text { Measuring ICT for } \\
\text { Development }\end{array}$ & $\begin{array}{l}\text { International of DESI (see above) } \\
\text { Core list of } 50 \text { indicators in } 5 \text { themes: } \\
\text { 1. ICT infrastructure and access } \\
\text { 2. ICT access and use by households and } \\
\text { individuals } \\
\text { 3. ICT access and use by enterprises } \\
4 \text {. ICT sector and trade in ICT goods } \\
5 \text {. ICT in education } \\
\text { 6. ICT in government } \\
\text { A supplemental list of } 26 \text { indicators for } \\
\text { adequately assessing specific targets of the } \\
\text { UN Sustainable Development Goals were } \\
\text { proposed in } 2020 \text {. }\end{array}$ & $\begin{array}{l}\text { Foley et al. (2018) } \\
\text { ITU (2021) }\end{array}$ \\
\hline
\end{tabular}

${ }^{a}$ ITU has proposed a change in the methodology behind the IDI but these have not been implemented at the time of writing. See ITU (2020) for more details

representative view, while sometimes being based on relatively small samples or subjective judgments (Berger \& Bristow, 2009). Often data is aggregated or weighted without commonality of approach. Indeed, this largely reflects the motivation for the G20 roadmap for a common framework for measuring the digital economy (DETF, 2020). In these cases, 
there is a significant risk of comparing apples to oranges (Berger \& Bristow, 2009). Finally, many of these indices are constructed on available data rather than required or ideal data.

These issues also arise in composite indices seeking to measure the digital society or digital economy. Firstly, towns and rural communities typically do not have the same agency as national governments or urban municipal authorities. For example, towns and rural communities may have little or no (a) autonomy with respect to decision making, and/or (b) revenue generation ability. As discussed earlier, successful digital town initiatives require a broad concept of community governance that, as per Leach and Percy-Smith (2001), involves multi-agency working and selforganising networks that cut across organisational and stakeholder boundaries. If this is a critical success factor then measurement frameworks must capture and make such governance measurable in a way that is not done so today.

Secondly, even where data is collected nationally, it may use sampling strategies which are not useful for decision-making at a town level. Indeed, town-level data may not be available at all, or, where available, is not representative due to the sampling strategy employed. For example, small-tomedium sized enterprises (SMEs) in rural communities are largely skewed towards micro-enterprises, those with less than ten employees. There is evidence to suggest that rural SMEs may be under-represented in international composite indices due to reliance on firm-level data from sources, such as Eurostat, that only collect data on enterprises with greater than ten employees. For example, the G20 Toolkit for Measuring the Digital Economy (G20 DETF, 2018), DESI (Digital Economy and Skills Unit, 2018, 2020, 2021), and I-DESI (Foley et al., 2018) all feature indicators that exclude micro-enterprises based on this criteria.

Thirdly, these national and city-level frameworks do not fully recognise the important role that all sectors of society play in rural towns and communities. For example, despite the significant role that civil society plays in modern economies and society as a whole, it does not feature as a discrete sector in digital measurement frameworks. As will be discussed in Chap. 5, civil society organisations are major employers and generators of significant economic value through expenditure. Digital technologies present nonprofit organisations and micro-enterprises in rural areas with a significant opportunity to overcome the limitations of their location yet are excluded or under-represented from critical policy making indicators. 
Fourthly, rural towns and communities face specific limitations due to their geographic location. As well as poorer broadband infrastructure, skills and human capital are generally lower in rural areas than in urban areas. Even in more developed economies, rural education attainment can significantly lag urban areas across education levels (OECD, 2017; Campbell, 2019). As higher education institutions are typically located in urban areas, rural communities often experience an out-migration of skilled individuals from rural to urban areas for tertiary education, many of which do not return due the greater employment opportunities and higher wages available in cities. Undoubtedly, digital business and remote working offer rural communities the opportunity to reverse out-migration trends however enabling infrastructure is required. This includes both local access to high-speed broadband and the provision of local education opportunities in and through ICTs. While digital infrastructure is prominent in all measurement frameworks, education is not. In measuring digital town readiness, we suggest these dimensions require specific attention.

To summarise, a comprehensive framework for measuring digital towns must be methodologically appropriate for the specific policy- and decisionmaking context. Consequently, it needs to be sufficiently flexible and scalable to allow for different local priorities and resources. When considering what factors should be measured with respect to the evolution and development of a digital town, it should not only include comprehensive data on the basic sectors of the local economy-individuals and households, government, business, and nonprofit organisations-but enabling infrastructure i.e., digital infrastructure, education, and community governance. It should be noted that these factors should not be considered fixed in stone. Additional thematic areas may be added or removed, or weighted differently, depending on the local context priorities. For example, more emphasis may be placed on a specific sector or set of economic activities e.g., tourism. Similarly, as technology advances, access, use and outcomes will change. Furthermore, the framework should allow for national and international comparison by including commonly used indicators. The OECD has called for rural areas to drive their own economic development rather than rely on the national government, specifically with respect to identifying and mobilising assets to improve economic performance (OECD, 2014). For both comprehensiveness and local planning, we argue that data needs to be collected at a local level thus the framework needs to be sufficiently easy to use, understand, and be communicated to support a bottom up community approach. 


\subsection{Conclusion}

This chapter introduces key terms and concepts in the digital society literature and emerging definitions of what a town is. From this literature, we define a digital town as "a geographic and information space that adopts and integrates information and communication technologies in all aspects of town life where a town consists of contiguous grid cells with a density of at least 300 inhabitants per $\mathrm{km}^{2}$, are at least $3 \%$ built up, and have a total population of at least 5,000." Our review of existing academic literature and digital town projects suggests a wide range of perspectives and rationales for adopting digital technologies at a town level. Notwithstanding this, it remains a relatively under-researched area particularly with respect to the longitudinal measurement of impact. We present a brief overview of commonly cited frameworks and composite indices for measuring digital society and digital economy, and discuss their applicability for rural towns and communities.

The remainder of this book is organised around seven dimensions based on the four sectors of the economy and three enabling infrastructures outlined in Sect. 1.4 above. Chapter 2 discusses the adoption and use of technologies by citizens and is followed by a similar discussion for public services (Chap. 3), businesses (Chap. 4) and civil society (Chap. 5). Then each of the enabling infrastructures are discussed i.e., infrastructure for digital connectivity (Chap. 6), education (Chap. 7), and governance (Chap. 8). In each chapter, the relevant dimension is defined and the benefits and challenges to adoption and use of technologies are discussed. Each chapter includes a discussion of how that dimension is measured in existing frameworks for the digital society and the digital economy, if at all. The book concludes in Chap. 9 with an overview of a digital town measurement framework including indicators and potential benchmarks.

\section{REFERENCES}

Ali, M. A., Alam, K., \& Taylor, B. (2020). Do social exclusion and remoteness explain the digital divide in Australia? Evidence from a panel data estimation approach. Economics of Innovation and New Technology, 29(6), 643-659.

Ashmore, F. H., Farrington, J. H., \& Skerratt, S. (2015). Superfast broadband and rural community resilience: Examining the rural need for speed. Scottish Geographical Journal, 131(3-4), 265-278.

Baig, A., Hall, B., Jenkins, P., Lamarre, E., \& McCarthy, B. (2020). The COVID-19 recovery will be digital: A plan for the first 90 days. McKinsey Digital, 14. 
Berger, T., \& Bristow, G. (2009). Competitiveness and the benchmarking of nations-A critical reflection. International Advances in Economic Research, $15(4), 378$.

Bosch, P., Jongeneel, S., Rovers, V., Neumann, H. M., Airaksinen, M., \& Huovila, A. (2017). CITYkeys list of city indicators. CityKeys. http://nws.eurocities. $\mathrm{eu} /$ MediaShell/media/CITYkeyslistofcityindicators.pdf

Bris, A., Chee, C. H., \& Lanvin, B. (2019). Smart City Index. The IMD World Competitiveness Center, Singapore, Singapore.

Campbell, C. (2019). Those left behind-Gaps in college attainment by race and geography. Center for American Progress. https://www.americanprogress. org/issues/education-postsecondary/reports/2019/06/27/471242/ those-left-behind/

Chakravorti, B., Chaturvedi, R., \& Tunnard, C. (2015). Where the digital economy is moving the fastest. Harvard Business Review.

Chambers, R. (2010). Paradigms, poverty and adaptive pluralism. IDS Working Papers, 2010(344), 1-57.

Chang, F. C., Miao, N. F., Chiu, C. H., Chen, P. H., Lee, C. M., Chiang, J. T., \& Chuang, H. Y. (2016). Urban-rural differences in parental Internet mediation and adolescents' Internet risks in Taiwan. Health, Risk \& Society, $18(3-4), 188-204$.

Craven, P., \& Wellman, B. (1973). The network city. Sociological Inquiry, $43(3-4), 57-88$.

Culot, G., Nassimbeni, G., Orzes, G., \& Sartor, M. (2020). Behind the definition of Industry 4.0: Analysis and open questions. International Journal of Production Economics, 226, 107617.

da Rocha, N. P. (2002). Aveiro-Digital town. In Advances in digitalgovernment (pp. 305-314). Springer.

Dameri, R. P. (2013). Searching for smart city definition: A comprehensive proposal. International Journal of Computers \& Technology, 11(5), 2544-2551.

de Waal, A. A. (2007). Successful performance management? Apply the strategic performance management development cycle! Measuring Business Excellence, 11, 4-11.

de Waal, A. A., \& Kourtit, K. (2013). Performance measurement and management in practice: Advantages, disadvantages and reasons for use. International Journal of Productivity and Performance Management, 62, 446-473.

Digital Economy and Skills Unit. (2018). The digital economy and society index (DESI) methodological note. https://ec.europa.eu/information_society/ newsroom/image/document/2018-20/desi-2018-methodology_ E886EDCA-B32A-AEFB-07F5911DE975477B_52297.pdf

Digital Economy and Skills Unit. (2020). DESI 2020-Digital economy and society index (DESI) 2020 questions and answers. https://ec.europa.eu/commission/presscorner/detail/en/qanda/20/1022 
Digital Economy and Skills Unit. (2021). The digital economy and society index (DESI) 2020. https://ec.europa.eu/newsroom/dae/document. cfm?doc_id=67086

Digitale Doerfer. (2020). Die digitalen doerfer. [Online]. https://www.digitaledoerfer.de/die-digitalen-doerfer/

Dijkstra, L., Poelman, H., \& Veneri, P. (2019). The EU-OECD definition of a functional urban area.

Dufva, T., \& Dufva, M. (2019). Grasping the future of the digital society. Futures, 107, 17-28.

European Commission. (2021). Creating a digital society. https://ec.europa.eu/ digital-single-market/en/creating-digital-society

European Network for Rural Development. (2018). Smart villages-Revitalising rural services. https://enrd.ec.europa.eu/publications/eu-rural-review-26smart-villages-revitalising-rural-services_en

Foley, P., Sutton, D., Wiseman, I., Green, L., \& Moore, J. (2018). International digital economy and society index 2018. The European Commission, Directorate-General of Communications Networks, Content and Technology.

G20 Digital Economy Task Force (DETF). (2018). G20 toolkit for measuring the digital economy. OECD. https://www.oecd.org/g20/summits/buenosaires/G20-Toolkit-for-measuring-digital-economy.pdf

G20 Digital Economy Task Force (DETF). (2020). A roadmap toward a common framework for measuring the digital economy. OECD.

Gartner. (2021). Digitization. Gartner IT Glossary. https://www.gartner.com/ en/information-technology/glossary/digitization

Hawkridge, D. (1990). Who needs computers in schools, and why? Computers \& Education, 15(1-3), 1-6.

Hervé-Van Driessche, K. (2001). Parthenay, the digital town: Myth or reality? Telematics and Informatics, 18(1), 5-15.

Hindman, D. B. (2000). The rural-urban digital divide. Journalism \& Mass Communication Quarterly, 77(3), 549-560.

Hosseini, S., Frank, L., Fridgen, G., \& Heger, S. (2018). Do not forget about smart towns. Business \& Information Systems Engineering, 60(3), 243-257.

Hsieh, H. N., Hou, C. Y., \& Chia, P. C. (2011, July). A study of smart town development strategies. In 2011 International Conference on Multimedia Technology (pp. 6684-6689). IEEE.

Hsieh, T. C., Yang, K. C., Yang, C., \& Yang, C. (2013). Urban and rural differences: Multilevel latent class analysis of online activities and e-payment behavior patterns. Internet research, 23(2), 204-228.

Isin, E., \& Ruppert, E. (2020). Being digital citizens. Rowman \& Littlefield Publishers.

ITU. (2018). Measuring the Information Society Report 2018. ITU Publications.

ITU. (2020). ICT Development Index 2020: A proposal. https://www.itu.int/ en/ITU-D/Statistics/Documents/events/egti2020/IDI2020_ BackgroundDocument_20200903.pdf 
ITU. (2021). The ICT Development Index (IDI): Conceptual framework and methodology. https://www.itu.int/en/ITU-D/Statistics/Pages/publications/mis/methodology.aspx

Katz, R., \& Callorda, F. (2018). The economic contribution of broadband, digitization and ICT regulation. ITU Publications.

Katz, R., Koutroumpis, P., \& Callorda, F. M. (2014). Using a digitization index to measure the economic and social impact of digital agendas. Info.

Leach, R., \& Percy-Smith, J. (2001). Local governance in Britain. Palgrave.

Lerch, M. (2017). Urban and rural fertility transitions in the developing world: A cohort perspective. Urban and rural fertility transitions in the developing world: A cohort perspective. Max Planck Institute for Demographic Research, Rostock, Germany.

Li, Y., \& Ranieri, M. (2013). Educational and social correlates of the digital divide for rural and urban children: A study on primary school students in a provincial city of China. Computers \& Education, 60(1), 197-209.

Lynn, T., Rosati, P., \& Endo, P. T. (2018). Toward the intelligent internet of everything: Observations on multidisciplinary challenges in intelligent systems research. In Technology, science, and culture: A global vision (p. 52).

Lynn, T., Rosati, P., Fox, G., Curran, D., O’Gorman, C., \& Conway, E. (2020). Addressing the urban-town-rural divide: The digital town readiness assessment framework. In ICDS 2020: The Fourteenth International Conference on Digital Society (pp. 1-10).

Lynn, T., Rosati, P., Fox, G., Curran, D., O'Gorman, C., \& Conway, E. (2022). Assessing the impact of COVID-19 on website technology penetration on businesses in rural towns. In Proceedings of the 55th Hawaii International Conference on System Sciences.

Martin, A. (2008). Digital literacy and the "digital society". Digital Literacies: Concepts, Policies and Practices, 30(2008), 151-176.

McQuillan, H. (2001, October). Ennis information age town: Virtuality rooted in reality. In Kyoto workshop on digital cities (pp. 139-151). Springer.

Mossberger, K., Tolbert, C. J., \& McNeal, R. S. (2007). Digital citizenship: The Internet, society, and participation. MIT Press.

Negroponte, N. (2015). Being digital. Vintage.

Nosalska, K., Piątek, Z. M., Mazurek, G., \& Rządca, R. (2019). Industry 4.0: Coherent definition framework with technological and organizational interdependencies. Journal of Manufacturing Technology Management. https://doi. org/10.1108/JMTM-08-2018-0238

Nusche, D., \& Minea-Pic. (2020). ICT resources in school education: What do we know from OECD work? OECD. https://www.oecd.org/officialdocuments / publicdisplaydocumentpdf/? cote=EDU/EDPC/SR/ $\mathrm{RD}(2020) 2 \&$ docLanguage $=\mathrm{En}$ 
OECD. (2014). Innovation and modernising the rural economy. https://read. oecd-ilibrary.org/urban-rural-and-regional-development/innovation-andmodernising-the-rural-economy_9789264205390-en\#page 1

OECD. (2017). Trends Shaping Education Spotlight 9. https://www.oecd.org/ education/ceri/spotlight9-CountryRoads.pdf

OECD \& European Union. (2020). A new perspective on urbanisation. https:// www.oecd-ilibrary.org/docserver/d0efcbda-en.pdf?expires=1630508068\&id $=\mathrm{id} \&$ accname $=$ guest $\&$ checksum $=81416$ BA322 B 3727 BE 17 DC C38BDF48D51

Park, S. (2017). Digital inequalities in rural Australia: A double jeopardy of remoteness and social exclusion. Journal of Rural Studies, 54, 399-407.

Park, S., \& Kim, G. (2015, March). Same access, different uses, and the persistent digital divide between urban and rural internet users. TPRC.

Philip, L., Cottrill, C., Farrington, J., Williams, F., \& Ashmore, F. (2017). The digital divide: Patterns, policy and scenarios for connecting the 'final few' in rural communities across Great Britain. Journal of Rural Studies, 54, 386-398.

Ragnedda, M., Ruiu, M. L., \& Addeo, F. (2020). Measuring digital capital: An empirical investigation. New Media \& Society, 22(5), 793-816.

Reis, J., Amorim, M., Melão, N., \& Matos, P. (2018, March). Digital transformation: A literature review and guidelines for future research. In World conference on information systems and technologies (pp. 411-421). Springer.

Sakurai, M., \& Kokuryo, J. (2018). Fujisawa sustainable smart town: Panasonic's challenge in building a sustainable society. Communications of the Association for Information Systems, 42(1), 19.

Scheerder, A., Van Deursen, A., \& Van Dijk, J. (2017). Determinants of Internet skills, uses and outcomes. A systematic review of the second-and third-level digital divide. Telematics and Informatics, 34(8), 1607-1624.

Schuler, D. (2001, October). Digital cities and digital citizens. In Kyoto workshop on digital cities (pp. 71-85). Springer.

Stern, M. J., Adams, A. E., \& Elsasser, S. (2009). Digital inequality and place: The effects of technological diffusion on internet proficiency and usage across rural, suburban, and urban counties. Sociological Inquiry, 79(4), 391-417.

Townsend, L., Sathiaseelan, A., Fairhurst, G., \& Wallace, C. (2013). Enhanced broadband access as a solution to the social and economic problems of the rural digital divide. Local Economy, 28(6), 580-595.

UNCTAD. (2021). Technology and Innovation Report 2021. United Nations Publications. https://unctad.org/page/technology-and-innovationreport-2021

Van Deursen, A. J., \& Helsper, E. J. (2015). The third-level digital divide: Who benefits most from being online? In Communication and information technologies annual. Emerald Group Publishing Limited. 
Vial, G. (2019). Understanding digital transformation: A review and a research agenda. The Journal of Strategic Information Systems, 28(2), 118-144.

Webster, F. (2006). Theories of the information society. Routledge.

Wei, L., \& Hindman, D. B. (2011). Does the digital divide matter more? Comparing the effects of new media and old media use on the education-based knowledge gap. Mass Communication and Society, 14(2), 216-235.

Wichmann, J., Wißotzki, M., \& Sandkuhl, K. (2021). Toward a smart town: Digital innovation and transformation process in a public sector environment. In Human centred intelligent systems (pp. 89-99). Springer.

Zavratnik, V., Kos, A., \& Stojmenova Duh, E. (2018). Smart villages: Comprehensive review of initiatives and practices. Sustainability, 10(7), 2559.

Open Access This chapter is licensed under the terms of the Creative Commons Attribution 4.0 International License (http://creativecommons.org/licenses/ by $/ 4.0 /$ ), which permits use, sharing, adaptation, distribution and reproduction in any medium or format, as long as you give appropriate credit to the original author(s) and the source, provide a link to the Creative Commons licence and indicate if changes were made.

The images or other third party material in this chapter are included in the chapter's Creative Commons licence, unless indicated otherwise in a credit line to the material. If material is not included in the chapter's Creative Commons licence and your intended use is not permitted by statutory regulation or exceeds the permitted use, you will need to obtain permission directly from the copyright holder.

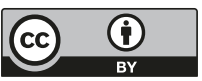

